\title{
Impact of Online Remote Education on the Learning Process among Nursing Students
}

\author{
Kawther Abdel Ghafar Ali ${ }^{\circledR}$, Hoda Esmat Mahmoud Khalil, Fatma Mokhtar El-Sharkawy \\ Faculty of Nursing, Misr University for Science and Technology, Giza, Egypt \\ Email:kawtherl@yahoo.com
}

How to cite this paper: Ali, K.A.G., Khalil, H.E.M. and El-Sharkawy, F.M. (2020) Impact of Online Remote Education on the Learning Process among Nursing Students. Open Journal of Nursing, 10, 810-830. https://doi.org/10.4236/ojn.2020.109057

Received: August 4, 2020

Accepted: September 13, 2020

Published: September 16, 2020

Copyright (๑) 2020 by author(s) and Scientific Research Publishing Inc. This work is licensed under the Creative Commons Attribution International License (CC BY 4.0).

http://creativecommons.org/licenses/by/4.0/

\section{(c) (i) Open Access}

\begin{abstract}
The period of existence and spread of Corona virus has led to the use of all means of remote education as an urgent necessity for all educational facilities, especially universities. Aim: Therefore, it was necessary to study the impact of online remote education on the learning process among nursing students through the study of two courses: health information management at 6th semester and gerontology nursing course at 4th semester. Tool of Data Collection: Online education assessment questionnaire is a modified tool comprised of forty statements used in paper survey and online survey. Sample: A purposive samples of 224 undergraduate students enrolled in two nursing courses during spring semesters 2019 and 2020. Setting: The field of study was the nursing faculty at Misr University for Science and Technology. Results: The main results illustrated positive impact of online remote education on the learning process as more than half of the students (53.9\%) had prior experience on online system use, and more than two third (62.5\%) were competent in mobile/computer applications. Almost, two third (59.3\%) agreed about online assessment experience, except that the online exam was anxious, and the time was insufficient to answer all questions. Also, more than two third (64.7\%) agreed on the elements of the learning process of the two nursing courses. Conclusion: The study concluded that there was positive impact of online education system on the learning process for nursing students except that the students were not able to decide that the remote online education system can replace traditional face-to-face learning. Recommendation: It is recommended to repeat the study on a large scale of nursing students to assess the possibility of inducing a positive impact of online remote education on clinical nursing courses if Corona virus still coexists. Future research is recommended to assess the strengths, weakness, opportunities and threats accompanied with remote learning management systems from teachers and students perspectives.
\end{abstract}




\section{Keywords}

Corona Virus, Learning Process, Nursing Students, Online Education, Online Assessment, Remote Education

\section{Introduction}

Online education management system afford various advantages that encourages students for autonomous learning and promote discovery for particular knowledge provided through presentations, videos, live interactive activities, tests that has automatic correction of questions, re-grading system, immediate scoring, and instant feedback, persistent assignments and assessment, training activities that govern the behaviors of students and teachers. Worldwide, due to the pandemic of Corona virus (COVID-19), all campuses were closed to reduce the infection rates, this closure made a sudden unplanned shift to use online education systems. Sounds professional before COVID-19, there were already some embracing of online education as a gate for development and promotion in education technology.

The introduction and implementation of a remote education policy albeit partially within colleges and schools can solve many overcrowding and pollution problems as well as save time and cost, and will prompt students and teachers to discover more information and enhance knowledge with an intellectual analysis that can be reflected in progress in all life science. According to Jane, et al., [1] technology advancement are grown rapidly and assisted nursing educators for delivering learning with several tools to participate students and improve their learning capacity. Recently, Duval, Sharples \& Sutherland, [2] emphasized that this advance of ever-changing technology has transformed the education sectors over the world, whereas many countries reshape their educational strategies to encounter the progressing of educational need.

So with or without existence COVID-19, teachers should not wait for other unknown or unexpected crises, teachers should focus in addition to students' knowledge, on students motivation through persistent education, summarize points of interest before the semester ends and regularly review materials, provide more encouragement, provide feedback, and provide inspiring and engaging materials using media multiplayer and technology, where teaching students with technology is one way to motivate students through using computers, internet, mobile phone, projector, etc., [3]. Coffman [4] had pointed previously that when technology tools driven by students, it become more complementary because students should discover technology by use of their current knowledge of technology, as they can explore and analyze tests themselves out of teaching and learning hours.

Initiatives that occurred in education had increased the value for the devel- 
opment of enrich computer-based environments of assessment that make students think with rational vision [5]. However, Candrlic, et al., [6] emphasized that online tests can replace old-fashioned paper-based tests for assessing students; however special attention must be awarded to the compound structure of the test. Also, Ghaderi [7] added that computer based tests developed in trendiness and will turn out to be a delivering test in the future. But the resistance of some academic teachers to apply these features of online systems could be a barrier to the inclusive benefits of their privileges [8].

Teachers are responsible for specifying outcomes of nursing education programs that are congruent with the current and future needs of the public. The curriculum reform movement of the 1980s focused on the importance of outcomes rather than process in optimizing the quality of teaching and learning in nursing education. This approach suggests that an orderly curriculum design does not take into account each learner's individual needs, abilities, and learning styles and that learner can reach the same goal by means of different paths [9].

New learning experiences and concepts learned and acquired are related to the previously known experiences to become a part of new learning experiences and concepts [10]. Online learning has become widely held due to its capabilities for offering better resilience access to contents and instructions at whichever time students want, in their places. So it is pivotal that researchers deliberate, and test the effectiveness of the online learning in educating students [11].

\section{Significance of the Study}

The future direction of universities focuses on activation of the use of educational technology, researches and increases the effectiveness of the educational process, which in turn contributes to achieving the mission of the university and the college from which the student will graduate.

Egyptian President Abdel Fattah El Sisi has directed the government to develop and expand the system of remote learning as a part of the state's strategy to deal with the next academic year in schools and universities, amid the corona virus crisis [12]. In this regard nursing students should broadly work on computer and information literacy to process online learning in an effective manner.

\section{Aim of the Study}

The study aimed to assess the impact of online remote education on the learning process among nursing students through using online education system on the study of two academic nursing courses; health information management systems course and gerontology nursing course.

\section{Research Hypothesis}

The study hypothesized that online remote education would achieve positive impact on the learning process among nursing students. 


\section{Subjects and Methods}

\subsection{Design}

A quasi experimental design was used in the study.

\subsection{Setting}

The research study was performed in the Faculty of Nursing at Misr University for Science and Technology (MUST). It is a private University and contains 14 Colleges affiliated to the Ministry of Higher Education. The Nursing program was the first program attained academic accreditation certificate in June 2016 amongst the private nursing faculties.

\subsection{Sample}

A purposive sample was used in the study of undergraduate nursing students enrolled to health information management course at sixth semester and gerontology nursing course at fourth semester, the researchers were the first academic staff implemented the online learning system in spring semester 2019 when was first started at the university, and these two first groups of students were participated voluntary in the paper based-survey. After that in spring semester 2020 during the pandemic outbreak of COVID-19, all nursing courses converted to online remote education to manage this urgent situation and a second two groups of nursing students of the same courses participated voluntary in the online based-survey. The total samples of the nursing students were 224 students, with response rate $45.2 \%$ from the total population (496) enrolled in these two nursing courses over spring semesters 2019 and 2020.

\subsection{Tool of Data Collections}

Online education assessment questionnaire was used in data collection and was modified by the researchers of the current study to correspond with the purpose of the study. The original tool [16] developed by the department of computer science and was evaluated by distance education expert from the Faculty of Education at kocaeli university, Turkey. Two sections from the original tool related to student agreement on "screen and interface design" and student agreement about "system use" were removed because the web design and features of system use were out of the scope of the current research. Another two sections were replaced about "evaluation of previous experience on online system use" and "evaluation of online learning process".

The modified tool composed of forty statements distributed to answer four dimensions in four sections; First one about students' prior experience on online system use which contained ten statements including two open-endedquestions; about grades of ICDL if has passed, and who assisted the student on use of smart learning website. The scoring system of this section was (Yes $=2$ and $\mathrm{No}=1$ ). 
Second section contained four statements to evaluate students' competence of mobile/computer applications. The scoring systems of this part was a 5-points likert scale ( 1 = poor, 2 = introductory, $3=$ none, 4 = good, $5=$ advanced).

Third and fourth section contained thirteen statements (per each section) about student evaluation on online course assessment experience and student evaluation on online learning process, respectively. The scoring systems of these two sections were 5-points likert scale $(1=$ strongly disagree, $2=$ disagree, $3=$ neutral, $4=$ agree, 5 = strongly agree).

The demographic data about student gender, age group and residency destinations were requested to be answered at the top of the questionnaire.

\subsection{Validity}

The modified questionnaire was reviewed by a group of experts from the academic professors of faculty of nursing at MUST, who agreed about the new added sections and suggested some modification on the language and adding two new questions (about ICDL grade and who assisted the student in using the online education system) with new arrangement of tool questions and sections. Content and face validity of the modified tool was revised for use.

\subsection{Reliability}

The internal consistency of the modified tool was calculated from the results of the piloted students displaying good reliability level as the Cronbach's alpha coefficient was assessed at 0.75 .

\subsection{Pilot Study}

The pilot study done on small scale of students (five students enrolled in nursing leadership and management course) to assess the feasibility of the components of the modified tool.

\subsection{Research Procedures}

On February 2019, the researchers have received training provided by information technology (IT) department at Misr University for Science and Technology (MUST) on the system use of smart learning "Moodle" "free online platform". The training was about the web site proper use, login, and formulation of the questions bank, categorizing questions, adding new questions, editing questions, preparing questions formats, opening and closing assessments schedule time, getting the final marks on the assessment, exams, grade book and logout from the website.

Every teacher was responsible for the instructional design, content creation, power points and audio-recording, videos, assignments, and all activities for the course including experimental test before conduction of real online assessments to familiarize students on the use of the system. During the conduction of the experimental test and real online assessments, the teachers supported students 
and opened chat to interact with problems facing them on spot. Traditional education synchronized with the online education as the teachers were explaining the course content in real class room with face-to-face interaction with the students. After the completion of the courses, the first survey was conducted through paper-based survey which distributed to two classes of health information management course at sixth semester and gerontology nursing course at the forth semester.

Simultaneously with the outbreak of Corona virus, in spring 2020 during this time there was a contingency demand for the use of online remote education and stop of in campus education. Therefore, the absence of face-to-face communication has required teachers to promptly constructing and converting the academic courses and shift students from in campus to online education. Until the completion of the semester there were continuous follow up to keep students as active learners by participation in interactive questions and answers sessions, tests, live presentations and open discussions, chatting and taking attendance to enhance commitment. After the course was completed, the second survey carried out through online-based questionnaire for the same two courses, then the responses were collated and percentages.

\subsection{Ethical Consideration}

At the commencement of embracing the online education system at MUST University, the researcher presented the idea of the current research to the Faculty Dean, who expressed her acceptance and support to the researchers. All the enrolled students in the two courses over the two semesters were encouraged to participate in the courses feedback surveys at the beginning of each course and informed about the research purpose and they were assured for no blame for any negative responses.

\subsection{Statistical Analysis}

The qualitative data of the students' responses in each semester through the first paper-based survey was computed in the form of frequencies and percentages by using SPSS version 20 after coding of each questionnaire sheet. The frequencies and percentages of students' responses for the online-based survey were computed electronically by the system, and then the sum of total frequencies and percentages were computed for each domain for the total samples in the two surveys.

\section{Results}

The analysis of data was portrayed over six parts: first one about students' population number and percent as enrolled to the courses, response rate of each sample and the total sample of all participated students, demographic data. Part two revealed the prior experiences of online system use. Part three illustrated students' competence of computer/mobile application. Part four presented student 
agreement about online assessment experience and part five demonstrated the students' evaluation of the online learning process and Part six revealed the total evaluation of main study components.

Table 1 illustrates the response rates of participated students from each group out of the total enrolled students in the nursing courses, higher responses appeared with the students at 6 th semesters, and the total response rate of the total sample was less than half $(45.2 \%)$ of the total enrolled students in the two courses. Regarding the gender, males' students were common (60.3\%) among the four groups of total sample. Most of the students (93.7\%) have age between 21 - 23 years. In addition, more than two third $(61.6 \%)$ of total sample were from rural areas.

Table 2 shows that the majority of students (82.2\%) have no TOEFL experience, while more than half have passed ICDL. Meanwhile, less than three quarters $(72.3 \%)$ never take previous training on computer skills except ICDL; conversely, all students have smart mobile phones and majority have email access. More than three quarters $(78.2 \%)$ of the total sample have done selftraining on smart learning and around less than quarter relied on informal training from teachers, peer colleague and friends respectively. Only (30.4\%) have previous web assessment while majority of student have used web for instructional purposes as per studied courses.

Table 3 presents that the majority of students were competent to use web browser $(76.4 \%)$, chat $(88.0 \%)$, and email (68.3\%), however $(38.4 \%)$ rated themselves as incompetent to use telnet and (15.6\%) have poor competence, $(26.8 \%)$ have introductory level.

Table 1. Demographic characteristics and comparison among the four groups of nursing students $(n=224)$.

\begin{tabular}{|c|c|c|c|c|c|}
\hline \multirow{2}{*}{ Students data } & \multicolumn{2}{|c|}{2019} & \multicolumn{2}{|c|}{2020} & \multirow{2}{*}{$\begin{array}{c}\text { Total Sample } \\
\text { No. (\%) }\end{array}$} \\
\hline & $4^{\text {th }}$ semester & $6^{\text {th }}$ semester & $4^{\text {th }}$ semester & $6^{\text {th }}$ semester & \\
\hline Registered students & 124 & 68 & 162 & 142 & $496(100 \%)$ \\
\hline Response rate & $50(40.3)$ & $58(85.3)$ & $54(33.3)$ & $62(43.7)$ & $224(45.2)$ \\
\hline \multicolumn{6}{|l|}{ Gender: } \\
\hline Female & $19(38.0)$ & $26(44.8)$ & $21(38.9)$ & $23(37.1)$ & 89 (39.7) \\
\hline Male & $31(62.0)$ & $32(55.2)$ & $33(61.1)$ & $39(62.9)$ & $135(60.3)$ \\
\hline \multicolumn{6}{|l|}{ Age: } \\
\hline $18-20$ & $2(4.0)$ & $4(6.9)$ & $1(1.9)$ & $2(3.2)$ & $9(4.0)$ \\
\hline $21-23$ & $47(94.0)$ & $54(93.1)$ & $51(94.4)$ & $58(93.6)$ & $210(93.7)$ \\
\hline $24-26$ & $1(2.0)$ & $0(0)$ & $2(3.7)$ & $2(3.2)$ & $5(2.3)$ \\
\hline \multicolumn{6}{|l|}{ Residency destination: } \\
\hline Rural & $26(52.0)$ & $41(70.7)$ & $34(63.0)$ & $37(59.7)$ & $138(61.6)$ \\
\hline Urban & $24(48.0)$ & $17(29.3)$ & $20(37.0)$ & $25(40.3)$ & $86(38.4)$ \\
\hline
\end{tabular}


Table 2. Students' prior experiences of online system use $(n=224)$.

\begin{tabular}{|c|c|c|}
\hline Items & $1=$ No & $2=$ Yes \\
\hline 1) Have you taken previous training on TOEFL? & $184(82.2)$ & $40(17.8)$ \\
\hline 2) Have you taken ICDL before? & $107(47.8)$ & $117(52.2)$ \\
\hline $\begin{array}{l}\text { 3) Have you taken previous training on computer skills } \\
\text { except ICDL? }\end{array}$ & $162(72.3)$ & $62(27.7)$ \\
\hline 4) Have you taken previous training on smart learning? & $175(78.2)$ & 49 (21.8) \\
\hline 5) Do you have an android mobile? & $0(0)$ & $224(100)$ \\
\hline 6) Do you have an email address? & $19(8.5)$ & $205(91.5)$ \\
\hline 7) Have you taken any web assessment? & $156(69.6)$ & $68(30.4)$ \\
\hline 8) Have you used web for instructional purposes? & $19(8.5)$ & $205(91.5)$ \\
\hline & \multicolumn{2}{|c|}{98 (91.6) In progress } \\
\hline What was your grade in ICDL? & $\begin{array}{l}29(2 \\
52(4 \\
36(3\end{array}$ & $\begin{array}{l}\text { rade } \\
\text { rade } \\
\text { rrade }\end{array}$ \\
\hline Who did help you in smart learning training? & $\begin{array}{r}175(78 \\
22(4) \\
17(34.7 \\
10(2\end{array}$ & $\begin{array}{l}\text { earning } \\
\text { acher } \\
\text { colleague } \\
\text { iends }\end{array}$ \\
\hline
\end{tabular}

Table 3. Students' competence with computer/mobile application $(\mathrm{n}=224)$.

\begin{tabular}{|c|c|c|c|c|c|}
\hline Items & 1 & 2 & 3 & 4 & 5 \\
\hline 1) Web browser & $9(4.0)$ & $36(16.0)$ & $8(3.6)$ & $99(44.2)$ & $72(32.2)$ \\
\hline 2) Chat & $18(8.0)$ & $9(4.0)$ & $0(0)$ & $99(44.2)$ & $98(43.8)$ \\
\hline 3) Telnet & $35(15.6)$ & $60(26.8)$ & $86(38.4)$ & $26(11.6)$ & $17(7.6)$ \\
\hline 4) E-mail & $20(8.9)$ & $34(15.2)$ & $17(7.6)$ & $45(20.1)$ & $108(48.2)$ \\
\hline
\end{tabular}

Table 4 displays that the majority of the students respectively found that the online assessment was fair (72.3\%), and cheating was difficult (71.9\%). Also, the majority (65.2\%) found that a page-by-page question layout makes them feel better in the exam, faster and better than paper-and-pencil form (64.7\%), and consistency with teaching style (66.5\%). Moreover, more than half $(52.7 \%)$ of students reported that exam date was announced in sufficient time and exams covers all parts that were explained (60.3\%), except in more than one quarter (29.9\%) of the students found that the online exam time was sufficient to answer all questions and was less anxious (26.3\%).

Table 5 reveals that the majority of the students agreed on the quality of audio-recording of power point presentations (93.3\%), videos (61.6\%), clarity of 
content objectives (58.5\%), use of student self-test (91.1\%), online learning interaction make them motivated (53.6\%), importance of learning activities (45.9\%), also more than two third (70.1\%) found that group participations in tasks accomplishment is better than individualized tasks (59.8\%). Effectiveness of rapport and respective relationship between teacher and student was reported by more than three quarters of the students (77.6\%). While, more than half $(59.3 \%)$ of the students reported that the system is contemporary but their responses about the online system can replace traditional face to face learning were distributed in approximated percentages on both sides of the scale.

Table 6 clarifies that the students' percentages at sixth semesters were higher than the students at fourth semesters in particular during the academic year 2020. Moreover, the table demonstrated the outcome of the study domains as the majority of total samples respectively; (53.9\%) have prior experience of online system use, (59.4\%) agreed on online assessment experience, $(62.5 \%)$ were competent to mobile/computer applications, and (64.7\%) agreed on the learning process of the nursing courses.

Table 4. Students evaluation on online assessment $(n=224)$.

\begin{tabular}{|c|c|c|c|c|c|}
\hline Items & 1 & 2 & 3 & 4 & 5 \\
\hline 5) Assessment was fair & $9(4.0)$ & $27(12.1)$ & $26(11.6)$ & $99(44.2)$ & $63(28.1)$ \\
\hline 6) Cheating was difficult & $54(24.1)$ & $9(4.0)$ & $0(0)$ & $71(31.7)$ & $90(40.2)$ \\
\hline $\begin{array}{l}\text { 7) System feedback helps me to reflect } \\
\text { on my competence in learning }\end{array}$ & $25(11.2)$ & 37 (16.5) & $19(8.5)$ & $62(27.7)$ & $81(36.1)$ \\
\hline $\begin{array}{l}\text { 8) Tracking past exam results makes } \\
\text { me understand my progress }\end{array}$ & $15(6.7)$ & $29(13.0)$ & $10(4.5)$ & $94(41.9)$ & $76(33.9)$ \\
\hline $\begin{array}{l}\text { 9) Statistical evaluation page gives a } \\
\text { detailed information on units where } \\
\text { I am good or unsuccessful }\end{array}$ & $17(7.6)$ & $30(13.4)$ & $51(22.7)$ & $43(19.2)$ & $83(37.1)$ \\
\hline $\begin{array}{l}\text { 10) Page-by-page questions makes me } \\
\text { feel better in the exam }\end{array}$ & $46(20.5)$ & $30(13.4)$ & $2(0.9)$ & $77(34.4)$ & $69(30.8)$ \\
\hline 11) Faster than paper-and-pencil & $27(12.1)$ & $22(9.8)$ & $23(10.3)$ & $85(37.9)$ & $67(29.9)$ \\
\hline 12) Better than paper-and-pencil form & $28(12.5)$ & $37(16.5)$ & $21(9.4)$ & $90(40.2)$ & $48(21.4)$ \\
\hline 13) Consistent with the teaching style & $34(15.2)$ & $23(10.3)$ & $18(8.0)$ & $80(35.7)$ & $69(30.8)$ \\
\hline $\begin{array}{l}\text { 14) Exam date was announced in } \\
\text { sufficient time }\end{array}$ & $53(23.6)$ & $37(16.5)$ & $16(7.2)$ & $48(21.4)$ & $70(31.3)$ \\
\hline $\begin{array}{l}\text { 15) Exam covers all parts that was } \\
\text { explained }\end{array}$ & $17(7.6)$ & 29 (12.9) & $43(19.2)$ & $62(27.7)$ & $73(32.6)$ \\
\hline $\begin{array}{l}\text { 16) Exam time was sufficient to } \\
\text { answer all questions }\end{array}$ & $72(32.2)$ & $54(24.1)$ & $31(13.8)$ & $40(17.8)$ & $27(12.1)$ \\
\hline 17) Less anxious & $73(32.6)$ & $79(35.3)$ & $13(5.8)$ & $31(13.8)$ & $28(12.5)$ \\
\hline
\end{tabular}


Table 5. Student evaluation on online learning process $(n=224)$.

\begin{tabular}{|c|c|c|c|c|c|}
\hline Items & 1 & 2 & 3 & 4 & 5 \\
\hline $\begin{array}{l}\text { 18) Volume and number of educational } \\
\text { units }\end{array}$ & $42(\mathbf{1 8 . 8 )}$ & $40(17.9)$ & $39(17.4)$ & $59(26.3)$ & $44(19.6)$ \\
\hline $\begin{array}{l}\text { 19) Quality of audio-recording of } \\
\text { learning lectures }\end{array}$ & $5(2.2)$ & $10(4.5)$ & $0(0)$ & $97(43.3)$ & $112(50.0)$ \\
\hline $\begin{array}{l}\text { 20) Videos used for demonstration of } \\
\text { content }\end{array}$ & $21(9.4)$ & $65(29.0)$ & $0(0)$ & $83(37.0)$ & $55(24.6)$ \\
\hline 21) Clarity of content objectives & $13(5.8)$ & $45(20.1)$ & $35(15.6)$ & $78(34.8)$ & $53(23.7)$ \\
\hline 22) Use of student self-test & $7(3.1)$ & $13(5.8)$ & $0(0)$ & $112(50.0)$ & $92(41.1)$ \\
\hline $\begin{array}{l}\text { 23) The level of online learning } \\
\text { interaction make me motivated }\end{array}$ & $45(20.1)$ & $59(26.3)$ & $0(0)$ & $58(25.9)$ & $62(27.7)$ \\
\hline 24) Importance of learning activities & $32(14.3)$ & $49(21.9)$ & $9(4.0)$ & $75(33.5)$ & $59(26.3)$ \\
\hline $\begin{array}{l}\text { 25) Group participations in tasks } \\
\text { accomplishment is better than } \\
\text { individualized tasks }\end{array}$ & 19 (8.5) & $37(16.5)$ & $11(4.9)$ & $104(46.4)$ & $53(23.7)$ \\
\hline $\begin{array}{l}\text { 26) Students attendances for each } \\
\text { lecture }\end{array}$ & $44(19.6)$ & $56(25.0)$ & $15(6.7)$ & $70(31.3)$ & $39(17.4)$ \\
\hline $\begin{array}{l}\text { 27) Effectiveness of rapport between } \\
\text { teacher and student through site chat }\end{array}$ & $2(0.9)$ & $28(12.5)$ & $20(8.9)$ & $84(37.5)$ & $90(40.2)$ \\
\hline $\begin{array}{l}\text { 28) Respect relationship between } \\
\text { teacher and student }\end{array}$ & $14(6.3)$ & $30(13.4)$ & $6(2.7)$ & $100(44.6)$ & $74(33.0)$ \\
\hline 29) Contemporary system & $25(11.2)$ & $47(21.0)$ & $19(8.5)$ & $48(21.4)$ & 85 (37.9) \\
\hline $\begin{array}{l}\text { 30) The online system can replace } \\
\text { traditional face to face learning }\end{array}$ & $65(29.0)$ & $42(18.8)$ & $20(8.9)$ & $56(25.0)$ & $41(18.3)$ \\
\hline
\end{tabular}

Table 6. Students evaluation of the entire online learning process among the four groups of nursing students $(\mathrm{n}=224)$.

\begin{tabular}{|c|c|c|c|c|c|}
\hline \multirow{4}{*}{ Study Domains } & \multicolumn{4}{|c|}{ No. (\%) of Participated Groups } & \multirow{4}{*}{$\begin{array}{c}\text { Total Sample } \\
\text { No. (\%) }\end{array}$} \\
\hline & \multicolumn{2}{|c|}{2019} & \multicolumn{2}{|c|}{2020} & \\
\hline & $4^{\text {th }}$ semester & $6^{\text {th }}$ semester & $4^{\text {th }}$ semester & $6^{\text {th }}$ semester & \\
\hline & $50(40.3)$ & $58(85.3)$ & $54(33.3)$ & $62(43.7)$ & \\
\hline $\begin{array}{l}\text { 1) Prior Experiences of } \\
\text { Online System Use. }\end{array}$ & $24(48.0)$ & $33(56.9)$ & $26(48.1)$ & $38(61.3)$ & $\begin{array}{l}121(53.9) \\
\text { Have Prior } \\
\text { Experience }\end{array}$ \\
\hline $\begin{array}{l}\text { 2) Competence in } \\
\text { Mobile/Computer } \\
\text { Applications. }\end{array}$ & $29(58.0)$ & $38(65.5)$ & $32(59.3)$ & $41(66.1)$ & $\begin{array}{l}140(62.5) \\
\text { Competent }\end{array}$ \\
\hline $\begin{array}{l}\text { 3) Evaluation of Online } \\
\text { Assessment. }\end{array}$ & $28(56.0)$ & $35(60.3)$ & $30(55.6)$ & $40(64.5)$ & $\begin{array}{l}133(59.4) \\
\text { Agreement }\end{array}$ \\
\hline $\begin{array}{l}\text { 4) Evaluation of Online } \\
\text { Learning Process. }\end{array}$ & $31(62.0)$ & $37(63.8)$ & $35(64.8)$ & $42(67.7)$ & $\begin{array}{l}145(64.7) \\
\text { Agreement }\end{array}$ \\
\hline
\end{tabular}




\section{Discussion}

Although online education puts an extra burden on teachers because it requires more hours to prepare more attractive and interactive content but still has advantage of working without distractions. Also, students have reported regret and dejection of losing face-to-face contact with teachers and colleagues.

Findings of the surveys of the present study revealed that the response rates of the two groups of students at 6th semesters of nursing informatics course were higher than the other two groups of students studying gerontology nursing course, meanwhile the total response rate of the total sample was less than half of the enrolled students in the two courses. Generally, the interpretation of this percentage is due to the fact that students are used to responding to questionnaires related to academic quality of courses in a quick and random manner as a mandatory step before showing the grades of the final exams, which led to a weak desire to deal with questionnaires as long as they are not forced to. In particular to the higher response rates in the nursing informatics course because students at the end of the course become more competent with computer skills and informatics.

Regarding the gender of the current participated students, males were common among the four groups of the total samples, which notable normal in the private nursing colleges than in governmental nursing colleges. Conversely with Fathalla, Salama, and Elwasefy [13] the authors reported that the female students were majority than male students in their study about the perception towards Moodle use as a pathway for education at Mansoura University.

The present study revealed that most of the participated students have age between $21-23$ years, and more than two third of total sample were from rural areas. It was notable that some students were inactive to access the remote on line courses as a result of poor internet connection which were clarified with classmates during running online discussions. This result was confirmed by Liyanagunawardena, et al., [14] that many students complain slowness of internet access through their study of blended learning in distance education. Also, Tien and $\mathrm{Fu},[15]$ reported that lack of digital connectivity has been found in many country regions, with lower income and far areas, especially rural or places of small mass population, which lead to a gap between effective and limited internet access.

Regarding to the participated students' prior experience to the online system use, the results of the present study indicated that, most of students have no TOEFL experience, and have never taken previous training on computer skills except for those who passed ICDL course where were as majority. The students of the present study at "MUST University" get the advantage of being provided with ICDL course at the first semester as a university requirement to equip them with the skills needed in complex future technology environment but unfortunately some students postpone the course until graduation because they get negative perception from some old students who failed in the course, this fact 
known from the researcher role as an academic advisor. Also as illustrated in the aforementioned demographic data, the majority of the students come from rural areas where internet access and cyber facilities are not as good or available as in urban areas which in turn lead to ineffective skills of computer, internet and as well online system use.

Also the present study clarified that most of students have smart mobile phones and majority have private email access and have done self-training on smart learning of Moodle system, while little percentage of students relied on informal training from teachers, peer colleague and friends respectively. In consistent with Fathalla, Salama, and Elwasefy [13] most of participated students had computer and mobile and can access internet alongside the day.

As illustrated from the current study, the majorities of the participated students have not taken any previous web assessment but have used the web for instructional purposes through the current studied courses and for the academic advising. However amongst the four groups of the participated students more than half of them have prior experience with online system use. Equivalent to the study of Ozden, Erturk, and Sanli [16] most of the students had no prior experience with online assessment and more than one third of students had used the internet for instructional purposes, in addition, none of them had taken an online course before the research when examined the students' perceptions of online assessment in Turkey.

The current results clarified that, most of participated students evaluated themselves as competent to use the web browser, chatting, and emailing, conversely, in the use of telnet as less than one third were incompetent. However amongst the four groups of the participated students more than half of them were competent to mobile and computer applications which indicate to their good potentiality to deal with software and hardware technology. In this regard Bond, [17] had mentioned that nursing students have positive attitudes towards technology, despite poorer internet skills in the formal education in the practice of numerous applications as reported by Maag, [18]. Therefore, students should be assisted to acquire these skills to support their online activities [19]. Also, Hsu, et al., [20] asserted that it is beneficial to evaluate these skills regularly. In addition, the results of Forbes and Khoo [21] indicated that the experience enabled the teachers to assist in students' training for developing their skills and self-confidence to initiate more free inquiry into technology to support the pedagogical objectives through a study aimed to exploring the potential of students' generated podcasts as a method of communicating formative assessment at a distance.

Regarding the participated students' evaluation of the online assessments, the results of current study revealed that most of them found that the assessment was fair and that cheating was difficult. However, some students used some tricks to facilitate the cheating, which was reported by some students who scored poorly than their peers in the first test that the tricking students disseminates the correct answers through "WhatsApp" during making the home tests, moreover, 
they took screenshots during the test and then published the gathered questions and answers to their closed groups from "WhatsApp" and on printed paper for more of use in other tests. To overcome the fraud tricks, preventive measures were taken for the remaining tests to prevent cheating, included recurrence tests with maximizing the question bank, the use of multiple versions of tests, the use of random questions with shuffling of questions and choices, and the use of the computers labs when conducting the tests, but unfortunately due to COVID-19, the students returned to make exams at home, so limited time restrictions were added, in addition to this, cessation of feedback assistance which provides rationales on correct and wrong answers by the system during the exams has been made and only the overall grades were shown at the end of the exams. These safeguards resulted in a normal statistical distribution of the learning curve among all students on all tests.

This results was consistent with the study of Ozden, Erturk, and Sanli [16] about students' perceptions of online assessment, as fairness of the assessment process was assessed positively by most of the students, and for preventing online cheating, the authors had mentioned that questions were placed in a random order, and placement of the choices of the questions was also varied from user to user. Moreover, all exams were taken in the labs under observation of teachers. Congruent with other researchers [22] the majority of their students had evaluated the computerized assessment as better as paper-based assessment although experiencing it for the first time. Additionally, Ardid et al., [23] clarified that the use of computer-based assessment was a useful aid for combined assessment, observing a quite perfect balance between online assessment and old-fashioned offprint exams

The results of the present study illustrated that the majority of students agreed on the benefits of system feedback in tracking past exam results, and the statistical evaluation which indicates their progress and competency. In addition, the majority of them found that the layout of a page-by-page question makes them feel better in reading clearly the exam questions, also, the online exam was faster and better than paper-and-pencil form, and the exams were consistent with the teaching style. Moreover, more than half of the participated students reported that exam dates were announced in sufficient time and the exams covered all parts that were explained. These results were supported by similar published studies, Ozden, Erturk, and Sanli [16] most of their students believed that the system feedback assisted them to reflect their learning level, and their progress was increased by using the online system, also page-by-page questions made them feel better in the exam. In agreement with Al-Amri [24] over than half of the students owned a positive attitude to the common features of computer-based test, as it was at ease to navigate through the pages on computer than on paper, and more than one third found it easier to read the items of the test on the computer than on paper.

The current study results revealed that almost two third of the total samples 
agreed on the online assessment experience positively amongst the four groups of the participated students except that in the negative side more than half of the students found that the time was insufficient to answer all questions and to make overall revision on the whole exam as they couldn't return to the previous questions or pages, also the majority of them reported that the online exam was anxious despite that an experimental exam had been established prior the formal one to train and familiarize the students on the use and features of online exam. In the same side of the current study results Lee, [25] and Carless, [26] had reported that, students' satisfaction level is nearly associated with clarity of guidelines, rubrics and helpful feedback in evaluating effectiveness of online learning.

Students in many countries perceived the bioscience features of their nursing course as difficult, while quizzes with feedback assist their learning and weekly learning objectives may be useful in increasing their academic performance [1]. In further recent research conducted by Ardid, et al., [27] highlighted on some criticisms in terms of clarity of the questions as teacher not present in addition to the rigidity of the automatic scoring which may cause poor perception of some students. So it is remarkable to continually work on the design of questions, considering not only the final result but also the intervening results and procedure through setting strategies that advocate the positive features and to alleviate possible problems of limitations towards its use in a good and more effective merged assessment.

Regarding students evaluation of the components of the online learning process the present study have demonstrated that the majorities of students' responses were strongly centered on agreement about the quality of audio-recording of power point presentations, videos, clarity of content objectives, and online learning interaction make them motivated to the courses. In this context, Gray and DiLoreto, [28] indicated that achievement of supportive climate of learning and teaching take place when educators professionally supplement audio, video, with synchronized and a synchronized communication, with practical students' activities and others online means to involve students. Also, Southard, Meddaugh and France-Harris [29] concluded that using of high-impact videos feature increase students' attention to the content, in return give value to the educator and the course.

Parallel to the current study results, during suspension of COVID-19, a large survey conducted at Southeast University in China, on 39,854 students by Sun, Tang \& Zuo, [30] showed that students has requested adding recorded videos and live courses with supplementary interaction to increase students' participation and almost half of students believed that the intended teaching objectives were fulfilled. Also, Thurmond, [31] had argued that the purpose of students' interaction is to increase understanding of the course contents and attain its defined goals. The current result also consistent with the study of Harandi, [32] regarding students' motivation as the relation between the electronic learning and motivation of the students was affected significantly in Tehran at Alzahra 
University.

The present study revealed that, less than half of the students agreed on the educational units of the course, this result explained why the students was requesting from the teachers to lesser the number or the volume of the learning units at the beginning of education suspension as they assumed their inability of full understanding of the educational contents in the absence of face-to-face teaching. In this perspective, Siemens, et al., [33] confirmed that the needs for technological support for students are considered essentials for those who do not have the levels required for computer and information literacy and self-efficacy, and for understanding the underlying causes of student decline.

Regarding the use of student self-test, the present study result reveled that most of the students were satisfied on the placement of frequent self-tests post weekly content which aimed to help students and to avoid uncertainty of content objectives and examine their understanding of difficult questions. Consistent with Roediger \& Butler [34] the work of self-tests helps students to stimulate and activate memory, as retrieval of knowledge is one of the most powerful ways of enhancing and making learning more durable although its use still underutilized. In the same line, Bates [35] emphasized that teachers should give students several quizzes in a regular basis for practice to become accustomed with the tests. However, teachers and students recognized the benefits of computerized assessment and communicated the downsides and needs for well application [36].

Concerning importance of learning activities, and students participation in tasks accomplishment, the present study illustrated that less than half of the students agreed on the importance of the learning activities conversely near of two third of the students preferred participations in tasks accomplishment as a group better than individualized tasks. The reason for this result is that the individualized tasks may pressurize them into self-dependence, full responsibility, and fear of distraction or facing difficulties when dealing with the online system problems such as, lack of connectivity or slow networking as was reported by some students. Likewise with the current research result, Choi, [37] reported that peer-topeer learning in online learning environments improve satisfaction among students. While on contradictory to the current result, Baxter and Haycock, [38] found that some students see that peer-to-peer support has little value.

Moreover the result of current study displayed the effectiveness of rapport and respective relationship between teacher and students as was reported by the majority of the students, as noticed by the teachers that some students were tensioned during conversation with them despite that teachers were answering on all questions submitted from the students through the web in prompt time over seven days of the week which was more than the office hours allocated in meeting the students in the regular time before Corona virus outbreak. This behavior or attitude may be originated as a result of the quarantine of COVID-19 which restricted students' attendance of their traditional classes without making gra- 
dual movement to online learning management that caused them to worry about their educational path. In a shortly time, this tensioned behavior has disappeared due to the persistent efforts of teachers to motivate and reassure students about their worries.

In this respect Sun, Tang \& Zuo, [30] argued that most students agreed that teachers induced positive energy during classes to relief students' tension and anxiety. Other studies, Harandi, [32]; Swan and Shih [39] found that educator with strong presence alongside with the quality of course contents are vital aspects in courses that facilitate online student's engagement and learning successfully. Gray and DiLoreto, [28] mentioned that instituting educator presence in online courses can be accomplished by certain ways, through regular conversation with students, constant feedback and critical dialogue modeled by the teacher. However, there is a necessity to improve students' self-discipline and attention amid disruptions alike unstable speed of network, noisy atmosphere and a deficiency of professional equipment [30].

Regarding the research hypothesis the majority of the total samples amongst the four participated study groups of students were agreed on the fulfillment of the learning components with positive impacts on the learning process of the two nursing courses under study. This outcome indicates the importance of well-designed supportive learning components when remote education is used especially in nursing profession which value the building of interactive leadership amongst their students. In this concern, Lee, [25]; Gray and Diloreto, [28] argued that course design and various course components stimulates students satisfaction and perceived learning which can contribute to a positive results. In this respect, Fathalla, Salama, and Elwasefy [13] showed that the students' experience regarding use of Moodle system, was easy and effective as an educational tool, but was unsuitable for conducting activities of the course by slightly more than half of the nursing students. Therefore, the investigation of effectiveness of e-learning is worthwhile for not just the students but also for the educators as it helps them in refining their methods of teaching. Regular testing of the outcomes of e-learning and efficiency of knowledge transfer guide the teachers to employ techniques that can be more effective in transferring the education [40]

The present study also demonstrated that around two thirds of the students reported that the online education system was contemporary, despite that students' responses about the possibility of the online education system to replace the traditional education were fluctuating on both sides of the scale. This unspecified result indicates many perspectives that need further assessments which may include students inconvenience for the absence of real class room or doubt of secured replacement of the online education system, therefore, various models of online education systems have to be engaged and examined to relief students' worries and anxiety related to their achievement of good academic levels.

A literature review on the factors influencing e-learning and blended learning, Nortvig, Petersen, and Balle, [41] asserted that the design of these courses should 
strongly link between online and offline activities, between campus-related and practice related activities and between students, teachers and content. In addition, it was reported by Saba, [42] that the well-designed and effective delivery of online courses can stay endure to connect classroom boundaries together and bond formal learning to a larger area through an energetic online learning community.

Parallel to the current study outcome, the recent published study of online education by Peking University's in China, when the universities closed the campuses and enforced to launch online teaching due to outbreak of the COVID-19. The study highlighted on 5 principles as highly impacted ideologies of online learning summarized in 1) the relation between online educational designs and students learning are at high importance, 2) provision of effective educational information online, 3) sufficient assistance delivered to students by faculty teachers and instructors, 4) highly qualified participants to increase the depth and wide-ranging of students' learning, and 5) plan contingently to act with unforeseen events of online education platforms [43].

From an opposite side, Schmid, et al., [44] stated that, the adoption of online learning had revealed various disadvantages of teaching and learning in the online environment such as technology gaps, feelings of isolation, and the cost for the training of educators. Therefore, recognizing a great opportunity and numerous potential threats with the introduction of online learning programs, educators, policymakers, and other relevant stakeholders raised questions about whether instructional technology affects learning and contributes to student achievement.

The need to electronically interchange data and information is an obligation in today's civilization as the meaningful use of online education that gives the advantages of nursing students to possess the computer competencies when become a nurse beginner and later on playing the vital role as a nurse informatics in various healthcare settings, as the future of nursing depends on a profession that will continue to innovate using informatics to play an instrumental role in patient safety, change management, and quality improvement as evidenced by quality outcomes, enhanced workflow and user acceptance.

\section{Study Limitations}

Assessing the clinical nursing experience and planned clinical activities of the nursing students were not evaluated in this research.

\section{Conclusion}

Many dimensions have reveled from the present study by the majorities of the nursing students in health information management course and gerontology nursing course such as students' acceptance, potentials and feedback of online remote education which induced positive impact on the learning process although the students were not able to definitely decide if online remote education 
can fully replace in campus education.

\section{Recommendations}

In the light of the study results, the following points were recommended:

- The impact of remote education should be investigated in different settings through other core courses of nursing such as medical surgical, critical care, emergency, obstetrics and pediatrics nursing which requires direct patients' live practice.

- Further researches are recommended to study the academic teachers' feedback, adaptation, acceptance, and potentials related to online remote education.

- From the opposite side, the potential threats accompanied with remote learning management systems from teachers and students perspectives should be investigated as well.

\section{Acknowledgements}

Great thanks and appreciation are forward to the Faculty Dean Professor Dr. Fatma El-Sharkawy for her successful experience on the application of online education initiative which provided not only for the current research but also for whole online courses conducted during the academic year 2019/2020. Wherein, nursing faculty was the first at the university level to implement this system during education suspension caused by COVID-19. Also, we would like to thank the Education Technology Department, Eng. Adel Ali, Eng. Mustafa Mahmoud, Eng. Ayman Hussein respectively who provided necessary training on online education and were available at all times to give support for any technical problem with the system operationability.

\section{Conflicts of Interest}

The authors declare no conflicts of interest regarding the publication of this paper.

\section{References}

[1] Jane, K., Andrew, S., Salamonson, Y., Everett, B. and Davidson, P.M. (2010) Nursing Students' Perception of a Web-Based Intervention to Support Learning. Nurse Education Today, 30, 584-590. https://doi.org/10.1016/j.nedt.2009.12.005

[2] Duval, E., Sharples, M. and Sutherland, R. (2017) Technology Enhanced Learning: Research Themes. Springer, Berlin. https://doi.org/10.1007/978-3-319-02600-8

[3] Zhao, L. (2016) Motivation in Chinese Children's English Teaching. Open Journal of Social Sciences, 4, 185-188. https://doi.org/10.4236/jss.2016.45022

[4] Coffman, T. (2009) Engaging Students through Inquiry-Oriented Learning and Technology. Rowman \& Littlefield Education, Lanham.

[5] Rosen, Y. and Tager, M. (2014) Making Student Thinking Visible through a Concept Map in Computer-Based Assessment of Critical Thinking. Journal of Educational Computing Research, 50, 249-270. https://doi.org/10.2190/EC.50.2.f 
[6] Candrlic, S., Katic, M.A. and Holenko Dlab, M. (2014) Online vs. Paper-Based Testing: A Comparison of the Test Results. 37 th International Convention on Information and Communication Technology, Electronics and Microelectronics (MIPRO), Opatija, 26-30 May 2014, 775-780. https://doi.org/10.1109/MIPRO.2014.6859649

[7] Ghaderi, M. (2014) Comparing between Computer Based Test and Paper- and Pencil Based Tests. International Journal of Education \& Literacy Studies, 2, 36-38. https://doi.org/10.7575/aiac.ijels.v.2n.4p.36

[8] Debuse, J.C.W. and Lawley, M. (2016) Benefits and Drawbacks of Computer Based Assessment and Feedback Systems: Student and Educator Perspectives. British Journal of Educational Technology, 47, 294-301. https://doi.org/10.1111/bjet.12232

[9] Kathleen, G.B., Marilyn, O.H. and Teresa, S. (2015) Clinical Teaching Strategies in Nursing. 4th Edition, Springer Publishing Company, Berlin.

[10] Githinji, D.G. (2017) School Factors Influence Instruction of Kiswahili Grammar in Public Secondary Schools in Baringo Central Sub-County, Kenya. Unpublished Degree of Master of Moi University in Kiswahili Department of Curriculum and Instruction Educational Media.

[11] Castro, M.D.B. and Tumibay, G.M. (2019) A Literature Review: Efficacy of Online Learning Courses for Higher Education Institution Using Meta-Analysis. Education and Information Technologies.

[12] Egypt's Sisi Urges Expanding Remote Learning in Egypt amid the Pandemic of Coronavirus.

https://egyptfwd.org/Article/99/1821/Egypt-s-Sisi-urges-expanding-remote-learnin g-in-Egypt-amid

[13] Mostafa, F.M., Salama, H.A.M. and Ahmed, E.S. (2017) Introducing Moodle as a New Path for Nursing Education: Students' Perception, Experience and Barriers. American Journal of Nursing Research, 5, 243-249.

[14] Liyanagunawardena, T., Adams, A., Rassool, N. and Williams, S. (2014) Blended Learning in Distance Education: Sri Lankan Perspective. International Journal of Education and Development Using ICT, 10, 55-69. https://doi.org/10.11114/jets.v1i2.96

[15] Tien, F.F. and Fu, T.-T. (2008) The Correlates of the Digital Divide and Their Impact on College Student Learning. Computers and Education, 50, 421-436. https://doi.org/10.1016/j.compedu.2006.07.005

[16] Ozden, M.Y., Erturk, I. and Sanli, R. (2004) Students' Perceptions of Online Assessment: A Case Study. Journal of Distance Education, 19, 77-92.

[17] Bond, C.S. (2004) Surfing or Drowning? Student Nurses' Internet Skills. Nurse Education Today, 24, 169-173. https://doi.org/10.1016/j.nedt.2003.10.013

[18] Maag, M.M. (2006) Nursing Students' Attitudes toward Technology: A National Study. Nurse Educator, 31, 112-118. https://doi.org/10.1097/00006223-200605000-00007

[19] Wharrad, H.J., Cook, E. and Poussa, C. (2005) Putting Post-Registration Nursing Students Online: Important Lessons Learned. Nurse Education Today, 25, 263-271. https://doi.org/10.1016/j.nedt.2004.12.003

[20] Hsu, H.-M., Hou, Y.-H., Chang, I.-C. and Yen, D.C. (2009) Factors Influencing Computer Literacy of Taiwan and South Korea Nurses. Journal of Medical Systems, 33, 133-139. https://doi.org/10.1007/s10916-008-9173-5

[21] Forbes, D. and Khoo, E. (2015) Voice over Distance: A Case of Podcasting for Learning in Online Teacher Education. Distance Education, 36, 335-350. 
https://doi.org/10.1080/01587919.2015.1084074

[22] Jawaid, M., Moosa, F.A., Jaleel, F. and Ashraf, J. (2014) Computer Based Assessment (CBA): Perception of Residents at Dow University of Health Sciences. Pakistan Journal of Medical Sciences, 30, 688-691. https://doi.org/10.12669/pjms.304.5444

[23] Ardid, M., Gomez-Tejedor, J.A., Meseguer-Dueoas, J.M., Riera, J. and Vidaurre, A. (2015) Online Exams for Blended Assessment. Study of Different Application Methodologies. Computers \& Education, 81, 296-303. https://doi.org/10.1016/j.compedu.2014.10.010

[24] Al-Amri, S. (2007) Computer-Based vs. Paper-Based Testing: Does the Test Administration Mode Matter? BAAL Conference, 101-110.

[25] Lee, J. (2014) An Exploratory Study of Effective Online Learning: Assessing Satisfaction Levels of Graduate Students of Mathematics Education Associated with Human and Design Factors of an Online Course. The International Review of Research in Open and Distance Learning, 15, 111-132. https://doi.org/10.19173/irrodl.v15i1.1638

[26] Carless, D. (2015) Exploring Learning Oriented Assessment Processes. Higher Education, 69, 963-976. https://doi.org/10.1007/s10734-014-9816-Z

[27] Ardid, M., Riera, J., Gomez-Tejedor, J.A., Vidaurre, A. and Meseguer-Dueoas, J.M. (2018) Students' Perception of Auto-Scored Online Exams in Blended Assessment: Feedback for Improvement. Education, 21, 79-103. https://doi.org/10.5944/educxx1.19559

[28] Gray, J.A. and Diloreto, M. (2016) The Effects of Student Engagement, Student Satisfaction, and Perceived Learning in Online Learning Environments. International Journal of Educational Leadership Preparation, 11.

https://eric.ed.gov/?id=EJ1103654

[29] Southard, S., Meddaugh, J. and France-Harris, A. (2015) Can SPOC (Self-Paced Online Course) Live Long and Prosper? A Comparison Study of a New Species of Online Course Delivery. Online Journal of Distance Learning Administration, 18, 8. http://www.westga.edu/ distance/ojdla/summer182/southard meddaugh harris182 .html

[30] Sun, L., Tang, Y. and Zuo, W. (2020) Coronavirus Pushes Education Online. Nature Materials, 19, 687. https://doi.org/10.1038/s41563-020-0678-8

[31] Thurmond, V.A. (2003) Understanding Interactions in Distance Education: Defining Interaction and Strategies to Enhance Interactions in Web-Based Courses. Nurse Educator, 28, 237-241. http://www.itdl.org/Journal/Jan 04/article02.htm https://doi.org/10.1097/00006223-200309000-00013

[32] Harandi, S.R. (2015) Effects of e-Learning on Students' Motivation. Procedia-Social and Behavioral Sciences, 181, 423-430.

http://www.sciencedirect.com/science/article/pii/S1877042815031985

[33] Siemens, G., Gasevic, D. and Dawson, S. (2015) Preparing for the Digital University: A Review of the History and Current State of Distance, Blended, and Online Learning. https://linkresearchlab.org/PreparingDigitalUniversity.pdf

[34] Roediger, H.L. and Butler, A.C. (2013) Retrieval Practice (Testing) Effect. In: Pashler, H.L., Ed., Encyclopedia of the Mind, Sage Publishing Co., Los Angeles, 660-661.

[35] Bates, A.W. (2005) Technology, E-Learning and Distance Education. Routledge, New York. https://doi.org/10.4324/9780203463772

[36] Yuan, J. and Kim, C. (2015) Effective Feedback Design Using Free Technologies. 
Journal of Educational Computing Research, 52, 408-434. https://doi.org/10.1177/0735633115571929

[37] Choi, B. (2016) How People Learn in an Asynchronous Online Learning Environment: The Relationships between Graduate Students' Learning Strategies and Learning Satisfaction. Canadian Journal of Learning and Technology, 42.

https://eric.ed.gov/?id=EJ1098278 https://doi.org/10.21432/T24K7R

[38] Baxter, J.A. and Haycock, J. (2014) Roles and Student Identities in Online Large Course Forums: Implications for Practice. The International Review of Research in Open and Distributed Learning, 15. https://www.learntechlib.org/p/171424 https://doi.org/10.19173/irrodl.v15i1.1593

[39] Swan, K. and Shih, L.F. (2005) On the Nature and Development of Social Presence in Online Course Discussions. Journal of Asynchronous Learning Networks, 9, 115 136. https://olj.onlinelearningconsortium.org/index.php/olj/article/view/1788 https://doi.org/10.24059/olj.v9i3.1788

[40] CommLab (2015) How to Measure the Effectiveness of E-Learning Programs. https://blog.commlabindia.com/elearning-design/course-tracking-to-improve-elear ning-effectiveness

[41] Nortvig, A.M., Petersen, A.K. and Balle, S.H. (2018) A Literature Review of the Factors Influencing E-Learning and Blended Learning in Relation to Learning Outcome, Student Satisfaction and Engagement. The Electronic Journal of e-Learning, 16, 46-55. https://eric.ed.gov/?id=EJ1175336

[42] Saba, F. (2012) A Systems Approach to the Future of Distance Education in Colleges and Universities: Research, Development, and Implementation. Continuing Higher Education Review, 76, 30-37.

https://www.academia.edu/19788992/A Systems Approach to the Future of Dist ance Education in Colleges and Universities Research Development and Imple mentation

[43] Wei, B. (2020) COVID-19 and Online Teaching in Higher Education: A Case Study of Peking University. Human Behavior and Emerging Technologies, 2, 113-115. https://doi.org/10.1002/hbe2.191

[44] Schmid, R.F., Bernard, R.M., Borokhovski, E., Tamim, R.M., Abrami, P.C. and Surkes, M.A. (2014) The Effects of Technology Use in Postsecondary Education: A Meta-Analysis of Classroom Applications. Computers \& Education, 72, 271-291. https://www.semanticscholar.org/paper/The-effects-of-technology-use-in-postsecon dary-A-of-Schmid-Bernard/4e148efe3636f9b34253302f7f1d3ec2bb588134 https://doi.org/10.1016/j.compedu.2013.11.002 